\title{
DETECTION OF ENVIRONMENTAL POLLUTANTS BY MICROBIOLOGICAL EXAMINATION AND PESTICIDES RESIDUAL MEASUREMENT IN RAW MILK SAMPLES.
El-Fadaly,H.A.*;Olfat
A. Radwan ${ }^{\star *} ; M$.
M. Kassem ${ }^{\star \star \star}$;

A. M.A. El-Gamal ${ }^{\star \star \star \star}$ and Amany M. El-Deeb ${ }^{\star \star \star \star}$

* Microbilogy Dept., Damietta Fac. of Agric., Mans. Univ., Damietta, Egypt

**Pesticides Analysis Res. DepT., Central Agric. Pesticides Laboratory (CAPL), ARC, Giza, Egypt

*** Microbilogy Dept., Fac. of Agric., Mansoura Univ., Mansoura, Egypt

${ }^{* \star \star \star P r o v i c i n a l ~ L a b o r a t o r y ~ o f ~ M a n s o u r a, ~ A n i m a l ~ H e a l t h ~ R e s . ~ I n s t ., ~ A R C, ~}$ Dokki, Giza

\begin{abstract}
Thirty raw milk samples including buffalo farm, bulk tank milk and cow's farm, 10 of each were randomly collected. Samples were collected from different dairy milk places in Mansoura city, Dakahlia governorate during summer and winter of 2006\&2007. All samples were used for microbiological examination and to determine the residual of some pesticides. Obtained results represented the mean values of microbiological quality of raw milk on either general or specific cultivation media. Results exhibited high values of the microbial count in the tested raw milk samples appeared on tryptone glucose extract agar (TGEA), they were $82.03 \pm 79.19 \times 10^{3}$, $119.40 \pm 62.58 \times 10^{3}$ and $129.03 \pm 113.60 \times 10^{3} \mathrm{cfu} / \mathrm{ml}$ in examined buffalo, bulk tank, and cow's milk samples, respectively. Obtained results indicated that the pesticide residues concentrations in all samples collected during summer season were lower than that samples collected during winter season. Results showed that the mean values of aldicarb residue was the highst values in examined buffalo, bulk tank, and cow's milk samples, they were $0.0344,0.0391$ and $0.0129 \mathrm{mg} / \mathrm{kg}$, respectively. The residues levels of pesticides in different milk types were lower than the acceptable daily intake (ADI), in summer and winter seasons on contrast the residue concentration of aldicarb and carbofuran were higher than the ADI in winter season. Profenfos insecticide was found in all samples either times in summer or winter season.
\end{abstract}

\section{INTRODUCTION}

The presence of environmental pollution facilitate their entry into the food chain and thus increasing the possibility of them having toxic effects on human and animals. However, agriculture activities as the use of fertilizers and the irrigation of fields, can also be important sources of contamination of the environment, of the food chain and eventually of food products consumed by humans. Milk is a basic food in the human diet exposed to contamination with several types of microorganisms from different sources. Under suitable circumstances, these contaminant find their way to grow and multiply in the milk and its products leading to undesirable changes that rendering it of an inferior quality or even unfit for human consumption beside it may constitute a public health hazard. Klebsiella pneumoniae was isolated from $13.8 \%$ of 


\section{A. M.A. El-Gamal et al.}

examined milk samples (Alonso et al., 2002). Staphylococcus aureus was found in 38 out of 54 raw milk samples at concentration up to $8.9 \times 10^{5} \mathrm{cfu} / \mathrm{ml}$ (Rall et al., 2008). Pesticides are being extensively used against livestock ectoparasites and agricultural pests. The usage of these highly persistent pesticides has resulted in trace contamination of air, water and soil with their residues. The residues of these pesticides were accumulated in milkproducing animals such as cow's and buffaloes if they fed on contaminated grass, hay and inhaled (Licata et al., 2004). Eight organophosphorus pesticides residues were determined in raw milk samples, $30 \%$ of these samples were positive to acephate and chlorpyriphos contamination (Pagliuca et al., 2004).

The microbiological examination and pesticides residues measurement of raw milk samples in this study were evaluated.

\section{MATERIALS AND METHODS}

\section{Collection of samples:}

Thirty samples of raw milk, buffalo farm, bulk tank milk and cow's farm, were randomly collected from different farms and markets in Mansoura city, Dakahlia governorate. Each sample was divided into two sub samples, the first was used for microbiological examination, while the second one was used for the determination of pesticides residues.

\section{Microbiological examination:}

Cultivation media:

The composition of general and specific cultivation media used in this investigation for different purposes were according to the standard methods reported in APHA (1992). These media were tryptone glucose extract agar (TGEA) for counting the total bacteria, salmonella shigella agar (SSA) to detect Salmonella spp and Shigella spp, mannitol salt phenol red agar (MSPRA) for detection of Staphylococcus ssp., MacConkey agar (MaccA) for detecting coliform bacteria; Milk agar (MA) for isolation counting and screening of proteolytic bacteria, potato dextrose agar (PDA) for isolation of fungi and tryptose agar (TA) for detection of Listeria spp., Brucella spp. and other pathogenic bacteria .

\section{Chemical analysis:}

\section{Determination of pesticides residues in milk}

Samples were taken at 2, 5, 8, 10 and 12 week over the course of a summer and winter seasons during 2006-2007. Milk (50ml)was blended with ethyl acetate for organophosphorus (OP) pesticides and with $(10 \mathrm{ml})$ acetone for carbamate pesticides and sodium sulphate $(50 \mathrm{~g})$ was added and the mixture was shaken and then allowed to stand for 2-3 min. The upper layer was decanted, and $50 \mathrm{ml}$ aliquot was evaporated to dryness in a rotating film evaporator $\left(35^{\circ} \mathrm{C}\right)$. The residue was dissolved in hexane $(10 \mathrm{ml})$ and then extracted with $2 \times 25 \mathrm{ml}$ acetonitrile saturated with hexane. Combined acetonitrile phase were evaporated to dryness, as described above. The residue was dissolved in $2 \mathrm{ml}$ of hexane. The hexane extract after cleaning up was dried by passing through sodium sulphate anhydrous. The hexane 
extract was rotary evaporatored to few drops and quantitatively transferred to volumetric tube. The volume was adjusted to $1 \mathrm{ml}$ with hexane (Naik et al., 2000)

\section{Liquid chromatographic analysis:}

The residue of aldicarb, chlorpyrifos-methyl, carbofuran, methomyl and profenfos were analyzed using Agillent HPLC Series 1100 quartary pump, with ultra violet spectrophotometer detector and $\mathrm{C}_{18}$ stainless column $(2.4 \times 250 \mathrm{~mm})$. Duplicate injection $(1 \mu \mathrm{l})$ of calibration solution and each sample was injected and integrated area for each peak was recorded and standard curve. This was done at the Central Agriculture Pesticides Laboratory (CAPL), Agricultural Research Center (ARC), Dokki, Giza, Egypt.

Statistical analysis:

The experimental data were statistically analyzed using the analysis of variance by the factorial design method. This had been done in order to acertain weather the experimental observations of the tested parameters were real and the differences between them are significant (SAS, 2001).

\section{RESULTS AND DISSCUSION}

\section{Microbiological quality:}

The mean values $\pm S D$ of the microbiological examination of the tested raw milk samples collected in summer and winter 2006-2007 seasons are listed in Table 1. Tabulated data exhibited high values $\pm S D$ on tryptone

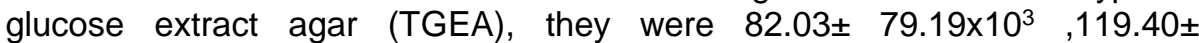
$62.58 \times 10^{3}$, and $129.03 \pm 113.60 \times 10^{3} \mathrm{cfu} / \mathrm{ml}$ in examined buffalo milk ,bulk tank milk and cow's milk samples, respectively. On specific cultivation media, the lowest mean values were found on Salmonella shigella agar (SSA), tryptose agar (TA) and potato dextrose agar (PDA), they were $2.10 \pm 4.33 \times 10^{3}, 9.30 \pm$ $18.00 \times 10^{3}$ and $5.43 \pm 10.5 \times 10^{3} \mathrm{cfu} / \mathrm{ml}$ in examined buffalo milk, bulk tank milk and cow's milk samples, respectively. On the level of the sampling season, the high value was in winter season, being $99.05 \pm 81.02 \times 10^{3} \mathrm{cfu} / \mathrm{ml}$, but in summer season it was $95.61 \pm 93.05 \times 10^{3} \mathrm{cfu} / \mathrm{ml}$ that exhibited on tryptone glucose extract agar (TGEA). Park et al., (2007) examined raw milk in Korea and they reported that Staph. aureus, Streptococcus spp., Enterococcus spp., Escherichia coli, Pseudomonas spp. and yeast could be isolated at different percentages. Muraoka et al., (2003) found Listeria monocytogenes in bulk milk samples, while Klossowska and Malinowski (2001) detected Staphylococcus aureus, Escherichia coli and Enterococcus faecalis in bulk tank milk. 
A. M.A. El-Gamal et al.

T1

8118 
Values of pesticides residue:

The results of pesticides analysis represented the determination of aldicarb, carbofuran, chlorpyrifos- methyl, methomyl and profenfos residues in buffalo milk samples collected in summer and winter 2006-2007 seasons are listed in Table 2. The presence of negligible restudies of pesticides in milk samples were taken at 5 times during summer season 2006-2007.

the average of detected pesticide residues in the buffalo milk after 2 weeks during summer season were (ND, 0.0025, ND, ND, and $0.0016 \mathrm{ppm}$ ) and were $(0.0031,0.0016,0.0015,0.0008$, and 0.0026 ppm after 5 weeks during summer season and were $(0.0010,0.0003,0.0014,0.0002$, and $0.0001 \mathrm{ppm})$ after 8 weeks during summer season and were $(0.0039,0.0004$, $0.0024,0.0009$, and $0.0008 \mathrm{ppm}$ ) after 10 weeks during summer season and were $(0.0015,0.0008,0.0006,0.0003$ and $0.0003 \mathrm{ppm})$ after 12 weeks during summer season for aldicarb, chlorpyrifos-methyl ,carbofuran, methomyl and profenfos, respectively. The average of the detected pesticides residues in buffalo milk samples after 2 weeks in winter season were $(0.0344,0.0005$, $0.0018,0.0008$, and $0.0004 \mathrm{ppm})$ and were $(0.0062$, ND, 0.0031, 0.0016, and $0.0013 \mathrm{ppm})$ after 5 weeks and were $(0.0099,0.0003,0.0017,0.0024$, and $0.0003 \mathrm{ppm})$ after 8 weeks and were $(0.0045,0.0008,0.0023,0.0011$, and $0.0006 \mathrm{ppm})$ after 10 weeks and were $(0.0152,0.0087,0.0048,0.0038$, and $0.0036 \mathrm{ppm}$ ) after 12 weeks at initial winter season for aldicarb, chlorpyrifosmethyl, carbofuran, methomyl and profenfos, respectively.

The pesticides residues in bulk tank milk samples were taken at 5 times during summer and winter2006-2007 season are listed in Table 3. The pesticides residues in the bulk tank milk samples after 2 weeks in summer were $(0.0021,0.0011,0.0001,0.0003$, and $0.0002 \mathrm{ppm})$ and were $(0.0010$, $0.0008,0.0009,0.0005$, and $0.0002 \mathrm{ppm}$ ) after 5 weeks and were 0.0010 , $0.0005,0.0003,0.0002$, and $0.0004 \mathrm{ppm})$ after 8 weeks and were $(0.0017$, $0.0007,0.0006,0.0004$, and $0.0004 \mathrm{ppm})$ after 10 weeks and were $(0.0022$, $0.0006,0.0005,0.0005$, and 0.005 after 12 weeks at initial summer season for aldicarb ,chlorpyrifos-methyl ,carbofuran, methomyl and profenfos, respectively. But the pesticides residues in bulk tank milk after 2 weeks in initial winter season were $(0.0391,0.0080, N D, 0.0094$ and $0.0009 \mathrm{ppm})$ and were $(0.0224,0.0132,0.0056,0.0058$, and $0.0008 \mathrm{ppm})$ after 5 weeks and were $(0.0207,0.0188,0.0045,0.0051$, and $0.0009 \mathrm{ppm})$ after 8 weeks and were $(0.0164,0.0097,0.0041,0.0041$ and $0.0022 \mathrm{ppm})$ after 10 weeks and were $(0.0323,0.0120, N D, 0.0080$ and $0.0011 \mathrm{ppm})$ after 12 weeks at initial winter season for aldicarb, chlorpyrifos-methyl, carbofuran, methomyl and profenfos, respectively.

The pesticide residues in cow's milk samples are listed in Table4. The average of detected pesticide residues in cow's milk after 2 weeks during summer season were $(0.0017,0.0081,0.0011,0.0008$, and $0.0006 \mathrm{ppm})$ and were $(0.0012,0.0004,0.0004,0.0003$, and $0.0001 \mathrm{ppm})$ after 5 weeks and were $(0.0039,0.0004,0.0029,0.0009$, and $0.0008 \mathrm{ppm})$ after 8 weeks and were $(0.0015,0.0008,0.0006,0.0003$ and $0.0003 \mathrm{ppm})$ after 10 weeks and were $(0.0081,0.0017,0.0011,0.0008$ and $0.0006 \mathrm{ppm})$ after 12 weeks in summer season for aldicarb, chlorpyrifos-methyl, carbofuran ,methomyl and profenfos, respectively. While the pesticides residues in cow's milk after 2 weeks during winter season were $(0.0066,0.0033,0.0032,0.0016$, and $0.0010 \mathrm{ppm}$ ) and were (ND, 0.0017, 0.0021, ND, and $0.0006 \mathrm{ppm}$ ) after 5 weeks and were $(0.0128,0.0007,0.0028,0.0032$, and $0.0008 \mathrm{ppm})$ after 8 weeks and were $(0.0129,0.0008,0.0026,0.0038$ and $0.0007 \mathrm{ppm})$ after 10 weeks and were (ND, 0.0038, 0.0030, ND, and $0.0010 \mathrm{ppm}$ ) after 12 at initial winter seasons for aldicarb, chlorpyrifos-methyl, carbofuran, methomyl and profenfos, respectively. 
A. M.A. El-Gamal et al.

T2

8120 
J. Agric. Sci. Mansoura Univ., 33(11), November, 2008

T3-4 


\section{A. M.A. El-Gamal et al.}

Pesticides can appear in milk due to several possible causes as use of insecticides directly on dairy cattle for ectoparasite control or animal feed manufactured from plant material that has been treated with insecticides and use of insecticides in stables or dairy factors. This study was carried out to determine the presence or absence of pesticide residues in milk samples (Buffalo, bulk tank and cow's) in summer and winter seasons during 2007. The pesticide residues concentration in all samples collected during summer season were lower than the pesticide residues concentration in all samples collected during winter season. The residues levels of pesticides in different milk types were lower than the acceptable Daily Intake (ADI), in summer and winter seasons on contrast the residue concentration of aldicarb and carbofuran were higher than the ADI in winter season. Profenfos insecticide was found in all samples at all times and in both summer and winter season, but its concentration within ADI value.

The results are in agreement with those obtained by Salas et al., (2003) who studied residues of 13 organophosphorus pesticides in four different milk brands with high distribution were collected biweekly during a 12 month period .Approximately 39.67 of the samples contained detectable levels of OP pesticide residues. Average residues of 13 OP pesticides measured were below MRL's. Pagliuca et al., (2004) who determined eight pesticide residues in milk, widely used in agriculture.

\section{REFERENCES}

Alonso, C.; Capita, R.; Carballo, J.; Bernardo, A. and Garcia, M. L. (2002): Changes in the Enterobacteriaceae populations throughout manufacturing and ripening of valdetega cheese. Dairy Sci. Abst., 64(12): 178

American public Health Association, APHA(1992). American Water work Association (AWWA) and water Environmental federation. $18^{\text {th }}$ Ed.,American Public Health Association,Washington.

Klossowska, A. and Malinowski (2001). Pathogens in raw milk which affect humans. Medycyna Weterynaryjna, 57(1): 28-31.

Licata, P. Trombetta, D.; Cristani, M.; Giofre, F.; Martino, D.; Calo. M. and Naccari, F. (2004). Levels of toxic and essential metals in samples of bovine milk from various dairy farm in Calabria, Italy. Environ. Int. J.,30(1): 1-6

Muraoka, W.; Gay, C.; Knowles, D. and Borucki, M. (2003). Prevalence of Listeria monocytogenes subtypes in bulk milk of the Pacific Northwest. J. Food Prot., 66(8): 1413-1419

Naik, V.N.; Pandit, G.G.; Sharma, S.; Srivastava, P.K. and Mahon Rao, A.M. (2000). Organochlorine pesticide residues in milk and milk products in Mumbai. Proceedings of the National symposium on the Environment. 5-7 June, : 254-257.

Pagliuca, G.; Gazzotti, T.; Zironi, E.; Pavoncelli, N. and Rosini, R. (2004). Proposal of an analytica méthode for determination of residues of organophosphours pesticide in milk by GLC-NPD. Vet. Research communications, 28:257-259 
Park, Y. K.; Koo, H. C., Kim, S. H; Hwang, S. Y; Jung, W. K. and Park, Y. H. (2007). The analysis of milk components and pathogenic bacteria isolated from bovine raw milk in Korea. J. Dairy Sci., 90(12): 5405-5414

Rall, V. L.; Vieira, F.P.; Rall, R.; Vieitis, R. L.; Fernandes, A. J.; Candeias, J. M., Cardoso, K. F. and Araujo, J. P. (2008). PCR detection of Staphylococcal enterotoxin genes in Staphylococcus aureus strains isolated from raw and pasteurized milk. Vet. Microbiol. J., 17(5): 22012209

Salas, J. W.; Gonalez, M.; Noa, M.; Perez, N.A.; Diaz, G.; Gutierrez, R.; Zazueta, H. and Osuna, I. (2003). Organophosphorus pesticide residues in Mexican commercial pasteurized milk. J. Agric. Food chem.., 51: 4468-4471

SAS (2001). SAS users Guide: Statistics (version 8 eds.) SAS Institute Inc., Gary, Nc.

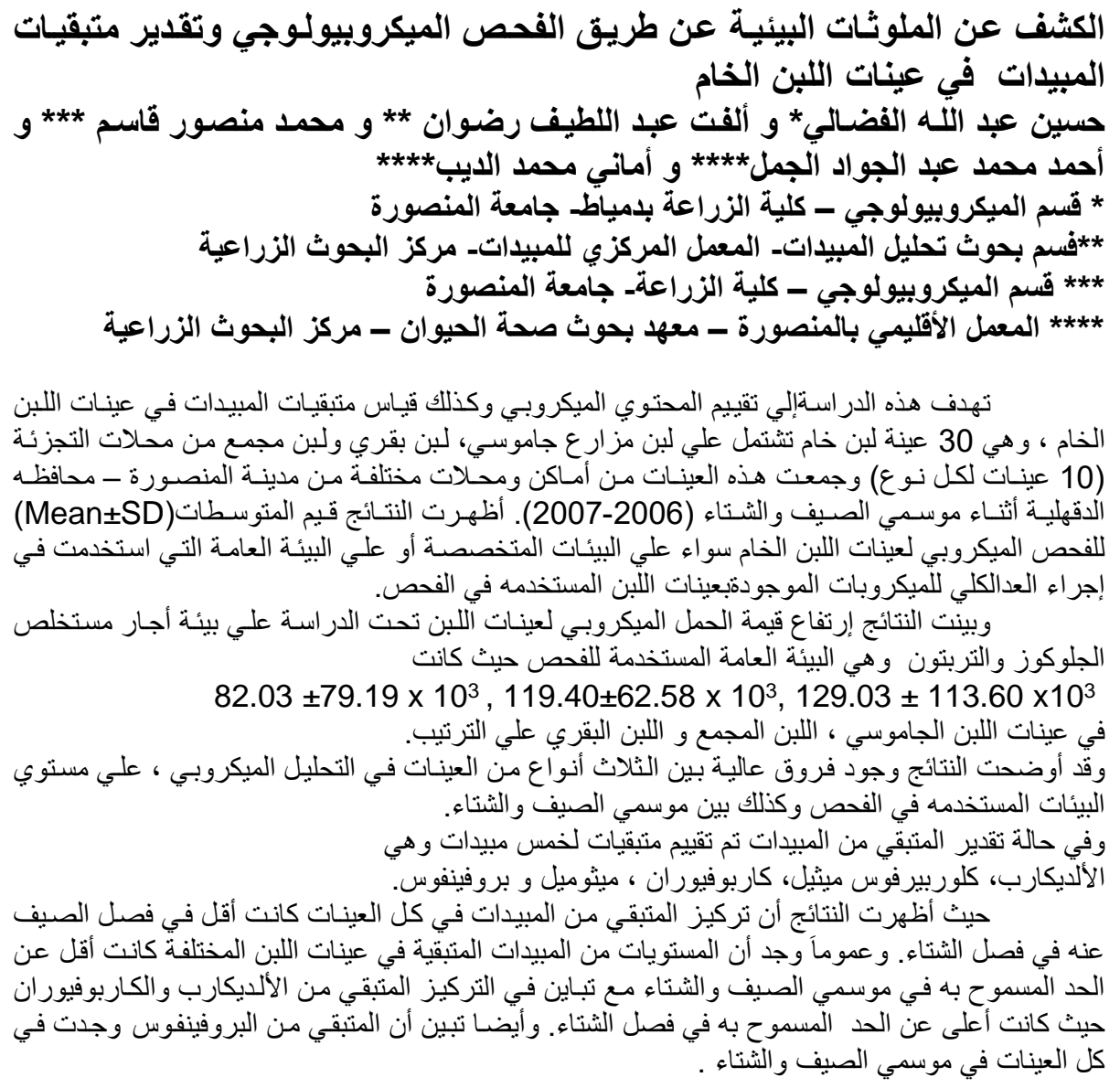


A. M.A. El-Gamal et al. 
J. Agric. Sci. Mansoura Univ., 33(11): 8115 - 8123, 2008

Table( 1): Mean values of the microbiological examination of the tested raw milk samples as affected by seasonal variations

\begin{tabular}{|c|c|c|c|c|c|c|c|c|}
\hline \multirow{3}{*}{ Items } & \multirow{3}{*}{$\mathbf{N}$} & \multicolumn{7}{|c|}{ Specific cultivation media $\times 10^{3} \mathrm{cfu} / \mathrm{ml}$} \\
\hline & & MA & MacCA & TGEA & PDA & SSA & TA & MSPA \\
\hline & & $\mathrm{X} \pm \mathrm{SD}$ & $\mathrm{X} \pm \mathrm{SD}$ & $X \pm S D$ & $\mathrm{X} \pm \mathrm{SD}$ & $\mathrm{X} \pm \mathrm{SD}$ & $X \pm S D$ & $\mathrm{X} \pm \mathrm{SD}$ \\
\hline \multicolumn{9}{|l|}{ Sample: } \\
\hline BTM & 30 & $40.20 \pm 39.02$ & $41.63 \pm 48.08$ & $119.40 \pm 62.58$ & $21.33 \pm 20.72$ & $19.13 \pm 41.57$ & $9.30 \pm 18.00$ & $32.00 \pm 50.21$ \\
\hline Buffalo & 30 & $58.43 \pm 81.20$ & $24.17 \pm 29.74$ & $82.03 \pm 79.19$ & $6.57 \pm 13.73$ & $2.10 \pm 4.33$ & $9.67 \pm 14.82$ & $26.60 \pm 57.42$ \\
\hline Cow & 30 & $63.90 \pm 87.96$ & $15.50 \pm 28.68$ & $129.03 \pm 113.60$ & $5.43 \pm 10.51$ & $29.27 \pm 43.69$ & $49.73 \pm 83.43$ & $69.40 \pm 93.93$ \\
\hline \multicolumn{9}{|l|}{ Season: } \\
\hline \multirow{2}{*}{$\begin{array}{c}\begin{array}{c}\text { Summer } 1 \\
\text { Winter } 2\end{array} \\
\end{array}$} & 75 & $65.32 \pm 78.56$ & $39.67 \pm 63.07$ & $95.61 \pm 93.05$ & $22.90 \pm 28.64$ & $31.91 \pm 48.09$ & $36.49 \pm 56.59$ & $54.69 \pm 75.49$ \\
\hline & 75 & $49.85 \pm 61.58$ & $20.32 \pm 28.01$ & $99.05 \pm 81.02$ & $28.67 \pm 40.11$ & $1.31 \pm 3.81$ & $1.09 \pm 4.71$ & $7.65 \pm 13.85$ \\
\hline \multicolumn{9}{|l|}{$\begin{array}{l}\text { Samplex Season } \\
\text { Interaction: }\end{array}$} \\
\hline BTM X1 & 15 & $54.87 \pm 42.99$ & $51.13 \pm 62.88$ & $126.80 \pm 68.33$ & $17.27 \pm 18.69$ & $35.33 \pm 54.59$ & $18.60 \pm 22.05$ & $54.73 \pm 63.61$ \\
\hline BTM X 2 & 15 & $25.53 \pm 29.05$ & $32.13 \pm 25.33$ & $112.00 \pm 57.68$ & $25.40 \pm 22.46$ & $2.93 \pm 6.02$ & $0.00 \pm 0.00$ & $9.27 \pm 8.36$ \\
\hline DOIII A 2 & 15 & $8493+10704$ & $3373+3710$ & $7740+10082$ & $933+1900$ & $127+293$ & $1932+1596$ & $5007+7509$ \\
\hline \begin{tabular}{|l|} 
Buffalo X 1 \\
Buffalo X 2 \\
\end{tabular} & 15 & $31.93 \pm 26.42$ & $14.60 \pm 16.12$ & $86.67 \pm 52.71$ & $3.80 \pm 3.63$ & $2.93 \pm 5.35$ & $0.00 \pm 0.00$ & $3.13 \pm 3.23$ \\
\hline Cow X1 & 15 & $9060+11501$ & $700+1129$ & $17487+11550$ & $1067+1303$ & $8553+4603$ & $4900+10063$ & $13620+9328$ \\
\hline Cow X 2 & 15 & $37.20 \pm 35.64$ & $24.00 \pm 37.71$ & $38.20 \pm 94.29$ & $\frac{10.01 \pm 10.00}{0.20 \pm 0.56}$ & $\frac{05.00 \pm 40.00}{0.00 \pm 0.00}$ & $\frac{49.00 \pm 100.63}{5.47 \pm 9.57}$ & $\frac{136.20 \pm 93.28}{2.60 \pm 3.29}$ \\
\hline \multicolumn{3}{|c|}{$\begin{array}{l}\text { BTM: Bulk tank milk } \\
\text { MA: Milk agar } \\
\text { SSA: Salmonella Shigella agar }\end{array}$} & \multicolumn{3}{|c|}{$\begin{array}{l}\text { TGEA: Tryptone glucose extract agar } \\
\text { PDA: Potato dextrose agar } \\
\text { MSPA: Mannitol salt phenol red agar }\end{array}$} & & \multicolumn{2}{|c|}{$\begin{array}{l}\text { TA: Tryptose agar } \\
\text { MacCA: MacConkey agar }\end{array}$} \\
\hline
\end{tabular}


A. M.A. El-Gamal et al.

Table (2):Pesticide residues $(\mathrm{mg} / \mathrm{Kg}$ ) in buffalo's milk during summer and winter 2007.

\begin{tabular}{|c|c|c|c|c|c|c|c|c|c|c|}
\hline \multirow{4}{*}{ Pesticide tested } & \multicolumn{10}{|c|}{ Season } \\
\hline & \multicolumn{5}{|c|}{ summer } & \multicolumn{5}{|c|}{ winter } \\
\hline & \multicolumn{10}{|c|}{ Sampling period } \\
\hline & 2 & 5 & 8 & 10 & 12 & 2 & 5 & 8 & 10 & 12 \\
\hline Aldicarb & ND & $\begin{array}{l}0.0031 \\
\pm 0.013\end{array}$ & $\begin{array}{c}0.0010 \\
\pm 0.0043\end{array}$ & $\begin{array}{r}0.0039 \\
\pm 0.0170\end{array}$ & $\begin{array}{r}0.0015 \\
\pm 0.0065\end{array}$ & $\begin{array}{c}0.0344 \\
\pm 0.0007\end{array}$ & $\begin{array}{c}0.0062 \\
\pm 0.0013\end{array}$ & $\begin{array}{c}0.0099 \\
\pm 0.0021\end{array}$ & $\begin{array}{r}0.0045 \\
\pm 0.0009\end{array}$ & $\begin{array}{c}0.0152 \\
\pm 0.0032\end{array}$ \\
\hline $\begin{array}{l}\text { Chlorpyrifos- } \\
\text { methyl }\end{array}$ & $\begin{array}{c}0.0025 \\
\pm 0.0330\end{array}$ & $\begin{array}{c}0.0016 \\
\pm 0.0213\end{array}$ & $\begin{array}{c}0.0003 \\
\pm 0.0041\end{array}$ & $\begin{array}{c}0.0004 \\
\pm 0.0064\end{array}$ & $\begin{array}{c}0.0008 \\
\pm 0.0110\end{array}$ & $\begin{array}{c}0.0005 \\
\pm 0.0003\end{array}$ & ND & $\begin{array}{c}0.0003 \\
\pm 0.0074\end{array}$ & $\begin{array}{r}0.0008 \\
\pm 0.0006\end{array}$ & $\begin{array}{c}0.0087 \\
\pm 0.0057\end{array}$ \\
\hline Carbofuran & ND & $\begin{array}{c}0.0015 \\
\pm 0.0884\end{array}$ & $\begin{array}{c}0.0014 \\
\pm 0.0816\end{array}$ & $\begin{array}{c}0.0024 \\
\pm 0.1688\end{array}$ & $\begin{array}{c}0.0006 \\
\pm 0.0343\end{array}$ & $\begin{array}{r}0.0018 \\
\pm 0.0051\end{array}$ & $\begin{array}{c}0.0031 \\
\pm 0.0087\end{array}$ & $\begin{array}{c}0.0017 \\
\pm 0.0051\end{array}$ & $\begin{array}{r}0.0023 \\
\pm 0.0067\end{array}$ & $\begin{array}{r}0.0048 \\
\pm 0.0136\end{array}$ \\
\hline Methomyl & ND & $\begin{array}{r}0.0008 \\
\pm 0.0056\end{array}$ & $\begin{array}{c}0.0002 \\
\pm 0.0017\end{array}$ & $\begin{array}{c}0.0009 \\
\pm 0.0062\end{array}$ & $\begin{array}{c}0.0003 \\
\pm 0.0024\end{array}$ & $\begin{array}{r}0.0008 \\
\pm 0.0003\end{array}$ & $\begin{array}{c}0.0016 \\
\pm 0.0005\end{array}$ & $\begin{array}{c}0.0024 \\
\pm 0.0008\end{array}$ & $\begin{array}{c}0.0011 \\
\pm 0.0004\end{array}$ & $\begin{array}{r}0.0038 \\
\pm 0.0012\end{array}$ \\
\hline Profenfos & $\begin{array}{c}0.0016 \\
\pm 0.0049\end{array}$ & $\begin{array}{c}0.0026 \\
\pm 0.0799\end{array}$ & $\begin{array}{c}0.0001 \\
\pm 0.0041\end{array}$ & $\begin{array}{r}0.0008 \\
\pm 0.0271\end{array}$ & $\begin{array}{r}0.0003 \\
\pm 0.0096\end{array}$ & $\begin{array}{c}0.0004 \\
\pm 0.0006\end{array}$ & $\begin{array}{c}0.0013 \\
\pm 0.0020\end{array}$ & $\begin{array}{c}0.0003 \\
\pm 0.0006\end{array}$ & $\begin{array}{c}0.0006 \\
\pm 0.0010\end{array}$ & $\begin{array}{r}0.0036 \\
\pm 0.0055\end{array}$ \\
\hline
\end{tabular}


J. Agric. Sci. Mansoura Univ., 33(11), November, 2008

Table (3): Pesticide residues (mg/Kg) in Bulk tank milk during summer and winter 2007.

\begin{tabular}{|c|c|c|c|c|c|c|c|c|c|c|}
\hline \multirow{4}{*}{ Pesticide tested } & \multicolumn{10}{|c|}{ Season } \\
\hline & \multicolumn{5}{|c|}{ summer } & \multicolumn{5}{|l|}{ inter } \\
\hline & \multicolumn{10}{|c|}{ Sampling period } \\
\hline & 2 & 5 & 8 & 10 & 12 & 2 & 5 & 8 & 10 & 12 \\
\hline Aldicarb & $\begin{array}{c}0.0021 \\
\pm 0.0091\end{array}$ & $\begin{array}{c}0.0010 \\
\pm 0.0077\end{array}$ & $\begin{array}{c}0.0010 \\
\pm 0.0043\end{array}$ & $\begin{array}{c}0.0017 \\
\pm 0.0073\end{array}$ & $\begin{array}{c}0.0022 \\
\pm 0.0034\end{array}$ & $\begin{array}{c}0.0391 \\
\pm 0.0080\end{array}$ & $\begin{array}{c}0.0224 \\
\pm 0.0047\end{array}$ & $\begin{array}{c}0.0207 \\
\pm 0.0044\end{array}$ & $\begin{array}{c}0.0164 \\
\pm 0.0035\end{array}$ & $\begin{array}{c}0.0323 \\
\pm 0.0068\end{array}$ \\
\hline Chlorpyrifos-methyl & $\begin{array}{c}0.0011 \\
\pm 0.1826 \\
\end{array}$ & $\begin{array}{c}0.0008 \\
\pm 0.0102 \\
\end{array}$ & $\begin{array}{c}0.0005 \\
\pm 0.0069 \\
\end{array}$ & $\begin{array}{c}0.0007 \\
\pm 0.0091 \\
\end{array}$ & $\begin{array}{c}0.0006 \\
\pm 0.0083 \\
\end{array}$ & $\begin{array}{c}0.0080 \\
\pm 0.0053 \\
\end{array}$ & $\begin{array}{c}0.0132 \\
\pm 0.0086 \\
\end{array}$ & $\begin{array}{c}0.0188 \\
\pm 0.0123 \\
\end{array}$ & $\begin{array}{c}0.0097 \\
\pm 0.0063 \\
\end{array}$ & $\begin{array}{c}0.0120 \\
\pm 0.0283 \\
\end{array}$ \\
\hline Carbofuran & $\begin{array}{c}0.0001 \\
\pm 0.0606\end{array}$ & $\begin{array}{c}0.0009 \\
\pm 0.0550\end{array}$ & $\begin{array}{c}0.0003 \\
\pm 0.0151\end{array}$ & $\begin{array}{c}0.0006 \\
\pm 0.0370\end{array}$ & $\begin{array}{c}0.0005 \\
\pm 0.0292\end{array}$ & ND & $\begin{array}{c}0.0056 \\
\pm 0.0161\end{array}$ & $\begin{array}{c}0.0045 \\
\pm 0.0128\end{array}$ & $\begin{array}{c}0.0041 \\
\pm 0.0139\end{array}$ & ND \\
\hline Methomyl & $\begin{array}{c}0.0003 \\
\pm 0.0020\end{array}$ & $\begin{array}{r}0.0005 \\
\pm 0.038\end{array}$ & $\begin{array}{c}0.0002 \\
\pm\end{array}$ & $\begin{array}{c}0.0004 \\
\pm 0.0027\end{array}$ & $\begin{array}{c}0.0005 \\
\pm 0.0034\end{array}$ & $\begin{array}{c}0.0094 \\
\pm 0.0029\end{array}$ & $\begin{array}{c}0.0058 \\
\pm 0.0016\end{array}$ & $\begin{array}{c}0.0051 \\
\pm 0.0016\end{array}$ & $\begin{array}{c}0.0041 \\
\pm 0.0013\end{array}$ & $\begin{array}{c}0.0080 \\
\pm 0.0025\end{array}$ \\
\hline Profenfos & $\begin{array}{c}0.0002 \\
\pm 0.0057 \\
\end{array}$ & $\begin{array}{c}0.0002 \\
\pm 0.0090 \\
\end{array}$ & $\begin{array}{c}0.0004 \\
\pm 0.0023 \\
\end{array}$ & $\begin{array}{c}0.0004 \\
\pm 0.0979 \\
\end{array}$ & $\begin{array}{c}0.0005 \\
\pm 0.1204 \\
\end{array}$ & $\begin{array}{c}0.0009 \\
\pm 0.0014 \\
\end{array}$ & $\begin{array}{c}0.0008 \\
\pm 0.0012 \\
\end{array}$ & $\begin{array}{c}0.0009 \\
\pm 0.0015 \\
\end{array}$ & $\begin{array}{c}0.0022 \\
\pm 0.0047 \\
\end{array}$ & $\begin{array}{c}0.0011 \\
\pm 0.0018 \\
\end{array}$ \\
\hline
\end{tabular}

ND = Not Detected.

All values $=$ means $\pm S E$

Table (4): Pesticide residues (mg/Kg) in cow's milk during summer and winter 2007.

\begin{tabular}{|c|c|c|c|c|c|c|c|c|c|c|}
\hline \multirow{4}{*}{ Pesticide tested } & \multicolumn{10}{|c|}{ Season } \\
\hline & \multicolumn{5}{|c|}{ summer } & \multirow{2}{*}{\multicolumn{5}{|c|}{ winter }} \\
\hline & \multicolumn{9}{|c|}{ Sampling period } & \\
\hline & 2 & 5 & 8 & 10 & 12 & 2 & 5 & 8 & 10 & 12 \\
\hline Aldicarb & $\begin{array}{c}0.0017 \\
\pm 0.0074 \\
\end{array}$ & $\begin{array}{c}0.0012 \\
\pm 0.0054 \\
\end{array}$ & $\begin{array}{c}0.0039 \\
\pm 0.0097 \\
\end{array}$ & $\begin{array}{c}0.0015 \\
\pm 0.0234 \\
\end{array}$ & $\begin{array}{c}0.0081 \\
\pm 0.0044 \\
\end{array}$ & $\begin{array}{c}0.0066 \\
\pm 0.0014 \\
\end{array}$ & ND & $\begin{array}{c}0.0128 \\
\pm 0.0027 \\
\end{array}$ & $\begin{array}{c}0.0129 \\
\pm 0.0027 \\
\end{array}$ & ND \\
\hline Chlorpyrifos-methyl & $\begin{array}{c}0.0081 \\
\pm 0.0053\end{array}$ & $\begin{array}{c}0.0004 \\
\pm 0.0318\end{array}$ & $\begin{array}{c}0.0004 \\
\pm 0.0064\end{array}$ & $\begin{array}{c}0.0008 \\
\pm 0.0245\end{array}$ & $\begin{array}{c}0.0017 \\
\pm 0.0113\end{array}$ & $\begin{array}{c}0.0033 \\
\pm 0.0026\end{array}$ & $\begin{array}{c}0.0017 \\
\pm 0.0011\end{array}$ & $\begin{array}{c}0.0007 \\
\pm 0.0005\end{array}$ & $\begin{array}{c}0.0008 \\
\pm 0.0005\end{array}$ & $\begin{array}{c}0.0038 \\
\pm 0.0025\end{array}$ \\
\hline Carbofuran & $\begin{array}{c}0.0011 \\
\pm 0.0330\end{array}$ & $\begin{array}{c}0.0004 \\
\pm 0.0239\end{array}$ & $\begin{array}{c}0.0029 \\
\pm 0.0052\end{array}$ & $\begin{array}{c}0.0006 \\
\pm 0.0091\end{array}$ & $\begin{array}{c}0.0011 \\
\pm 0.0134\end{array}$ & $\begin{array}{c}0.0032 \\
\pm 0.0021\end{array}$ & $\begin{array}{c}0.0021 \\
\pm 0.0062\end{array}$ & $\begin{array}{c}0.0028 \\
\pm 0.0080\end{array}$ & $\begin{array}{c}0.0026 \\
\pm 0.0079\end{array}$ & $\begin{array}{c}0.0030 \\
\pm 0.0092\end{array}$ \\
\hline Methomyl & $\begin{array}{c}0.0008 \\
\pm 0.0028 \\
\end{array}$ & $\begin{array}{c}0.0003 \\
\pm 0.0020 \\
\end{array}$ & $\begin{array}{c}0.0009 \\
\pm 0.0062 \\
\end{array}$ & $\begin{array}{c}0.0003 \\
\pm 0.0024 \\
\end{array}$ & $\begin{array}{c}0.0008 \\
\pm 0.0028 \\
\end{array}$ & $\begin{array}{c}0.0016 \\
\pm 0.0005 \\
\end{array}$ & ND & $\begin{array}{c}0.0032 \\
\pm 0.0010 \\
\end{array}$ & $\begin{array}{c}0.0038 \\
\pm 0.0010\end{array}$ & ND \\
\hline Profenfos & $\begin{array}{c}0.0006 \\
\pm 0.0084 \\
\end{array}$ & $\begin{array}{c}0.0001 \\
\pm 0.0059\end{array}$ & $\begin{array}{c}0.0008 \\
\pm 0.0271\end{array}$ & $\begin{array}{c}0.0003 \\
\pm 0.0096 \\
\end{array}$ & $\begin{array}{c}0.0006 \\
\pm 0.0038 \\
\end{array}$ & $\begin{array}{c}0.0010 \\
\pm 0.0016 \\
\end{array}$ & $\begin{array}{c}0.0006 \\
\pm 0.0011 \\
\end{array}$ & $\begin{array}{c}0.0008 \\
\pm 0.0013 \\
\end{array}$ & $\begin{array}{c}0.0007 \\
\pm 0.0013\end{array}$ & $\begin{array}{c}0.0010 \\
\pm 0.0016 \\
\end{array}$ \\
\hline
\end{tabular}

ND = Not Detected. 
A. M.A. El-Gamal et al. 